\title{
LAS ENTIDADES LOCALES Y LA PROTECCIÓN DE LOS
} ANIMALES

Francisco Capacete González

A pesar de vivir en un mundo globalizado e interconectado en el que se hace necesario disponer de una perspectiva amplia para actuar eficazmente -por ejemplo, para poder luchar contra el tráfico ilegal de animales exóticos-, la acción local es de gran importancia en la protección de los animales. En España los Municipios y otras Entidades locales, tienen atribuidas una serie de competencias relacionadas con los animales. Esta transferencia competencial permite al ciudadano actuar en proximidad en la defensa de los derechos de los animales.

La Constitución española (CE) garantiza la autonomía de los Municipios (artículo 140) y señala que las Haciendas locales deben disponer de los medios suficientes para el desempeño de sus funciones (artículo 142). Las competencias de las Entidades locales se clasifican en competencias propias atribuidas por la Ley o competencias atribuidas por delegación. Se regulan fundamentalmente en los artículos 7, 25, 27 y 36 de la Ley Reguladora de las Bases del Régimen Local.

En este breve artículo nos centramos en aquellas competencias que guardan relación directa con la protección animal, obviando todas las demás que no vienen al caso. Las competencias relacionadas con los animales, deben ser desarrolladas y ejecutadas según lo dispuesto en el artículo 13 del Tratado de Funcionamiento de la Unión Europea ${ }^{1}$, por lo que tendrán en cuenta que los animales como seres sensibles deben gozar de unas condiciones adecuadas de bienestar.

\footnotetext{
${ }^{1} \mathrm{Al}$ formular y aplicar las políticas de la Unión en materia de agricultura, pesca, transporte, mercado interior, investigación y desarrollo tecnológico y espacio, la Unión y los Estados miembros tendrán plenamente en cuenta las exigencias en materia de bienestar de los animales como seres sensibles, respetando al mismo tiempo las disposiciones legales o administrativas y las costumbres de los Estados miembros relativas, en particular, a ritos religiosos, tradiciones culturales y patrimonio regional.
} 


\section{dA derecho ANIMAL}

El artículo 25 de la LRBRL recoge las competencias específicas de los municipios, señalando que los mismos ejercerán en todo caso como competencias propias en las siguientes materias:

i) Ferias, abastos, mercados, lonjas y comercio ambulante. Los Ayuntamientos pueden regular cómo debe ser el trato a los animales en estos fueros comerciales, estableciendo las condiciones mínimas de bienestar tanto durante el traslado, como durante su permanencia en los mercados o lugares habilitados para la venta ambulante.

j) Protección de la salubridad pública. En este epígrafe entran todos aquellos temas que tienen que ver con las condiciones de salud pública, esto es, las condiciones saludables del entorno urbano o rural en el municipio. La proliferación de animales sin control puede afectar a la salubridad pública por cuanto pueden convertirse en vectores de transmisión de zoonosis. La defecación incontrolada de los animales en los espacios públicos también afecta a la salubridad. Y aún las pésimas condiciones de establecimientos y viviendas privadas que las conviertan en focos de infección y contaminación. El Ayuntamiento, por consiguiente, debe regular estos supuestos en los que los animales pueden verse implicados, estableciendo las condiciones mínimas de salubridad, tanto en espacios públicos como en los privados.

El artículo 27.3. de la LRBRL establece que para evitar duplicidades administrativas las Comunidades Autónomas (CC.AA.) podrán delegar en las Corporaciones locales, entre otras, las siguientes competencias:

b) Protección del medio natural. Para que esta disposición sea coherente con el artículo 148.1.9. - de la CE, debe entenderse por "medio natural" el medio ambiente, dado que las CC.AA. tiene competencia exclusiva en gestión y protección del medio ambiente y no del medio natural. Podemos definir el Medio Ambiente como "el conjunto de factores naturales y antropogénicos y aquellos elementos que afectan al equilibrio ecológico, a 
la calidad de la vida, a la salud humana, al interés cultural e histórico y al paisaje"2. Los Ayuntamientos puede regular la protección de todos los animales que forman parte de los ecosistemas pertenecientes al Municipio, así como la de aquello animales que integran las manifestaciones culturales y las tradiciones del municipio.

k) Comunicación, autorización, inspección y sanción de los espectáculos públicos. Los Ayuntamientos están legitimados para regular el uso de los animales en los espectáculos públicos, estableciendo estándares de protección adecuados al bienestar animal, así como prohibiendo o no autorizando aquellos espectáculos públicos en los que se pueda lesionar la integridad física y psicológica de los animales.

Esas otras materias que pueden delegar son las que el artículo 148 de la CE establece como propias de las CC.AA. y que son las siguientes:

7. a agricultura y ganadería, de acuerdo con la ordenación general de la economía. 9. ${ }^{a}$ La gestión en materia de protección del medio ambiente.

11. - La pesca en aguas interiores, el marisqueo y la acuicultura, la caza y la pesca fluvial.

12.. Ferias interiores.

21. - Sanidad e higiene.

Aquellos Municipios que tengan delegadas estas competencias podrán regular las condiciones de bienestar de los animales de granja, pudiendo establecer medidas que mejoren la protección regulada en normas estatales y europeas. Lo mismo con la caza, la pesca, el marisqueo, las ferias interiores, la sanidad y la higiene, cuidando en todo caso de no limitar derechos reconocidos en las leyes estatales. Por ejemplo, las Corporaciones locales no pueden prohibir la caza porque es una actividad regulada por una ley estatal, pero sí pueden regular los periodos de caza, los medios de caza y las capturas máximas para proteger mejor a las especies cinegéticas. Tampoco pueden

\footnotetext{
${ }^{2}$ Confer KISS A.C. Y SHELTON D.: Manual of European Environmental Law,
} Cambridge Grotius. 1993. $1^{\text {a }}$ Edición. 
prohibir festejos como los taurinos, pero sí pueden limitar el acceso a los mismos a los menores de edad o imponer aquellas medidas de seguridad y salubridad que considere oportunas.

Estas son las competencias que tienen y que pueden asumir las Entidades locales en España. No todas ellas las han asumido ni regulado. Los ciudadanos tienen la oportunidad de exigir a sus respectivos ayuntamientos y consejos que asuman sus responsabilidades en la protección animal. Ya sea a través de la participación directa, ya sea con la elección de los representantes políticos, pueden exigir el cumplimiento de las competencias propias y delegadas.

Para que las Entidades locales puedan cumplir con todas estas responsabilidades necesitan una suficiente financiación, personal formado y medios materiales suficientes. A día de hoy, pocos son los municipios que pueden implementar los medios materiales y humanos para cumplir con todas sus competencias en materia de protección animal. Sin embargo, no pueden hacer dejadez de sus funciones. Si, por ejemplo, a causa de la proliferación de una especie animal, los niños de un colegio se contagian de alguna bacteria o virus, el Ayuntamiento será el responsable y deberá indemnizar a los particulares por los daños y perjuicios sufridos. Y es que, en este hipotético caso, es el Ayuntamiento quien debe cuidar que el medio natural y la salubridad sean los adecuados. Si no protege a los animales que viven en el territorio del municipio y contraen enfermedades por falta de condiciones higiénicas, la responsabilidad, repetimos, será del Consistorio municipal ${ }^{3}$.

El papel de las Entidades locales en la protección animal es crucial y cada vez lo será más. Pensar globalmente y actuar localmente adquiere más significados y relevancia a la luz de las competencias que tiene atribuidas en materia de protección animal.

${ }^{3}$ CE. Artículo 106.2. Los particulares, en los términos establecidos por la ley, tendrán derecho a ser indemnizados por toda lesión que sufran en cualquiera de sus bienes y derechos, salvo en los casos de fuerza mayor, siempre que la lesión sea consecuencia del funcionamiento de los servicios públicos. 